\title{
From Germacarbonyl Compounds' Perspective: Glad to be Formed and Stable in the Real World ${ }^{\dagger}$
}

\author{
Pritam Mahawar, Pratima Shukla, Prakash Chandra Joshi, Dharmendra Singh, Selvarajan \\ Nagendran*
}

Germacarbonyl compounds are the germanium analogs of carbonyl compounds, and they require an inert atmosphere for stability. Making these compounds survive the ambient conditions was not feasible given the lability of the $\mathrm{Ge}=\mathrm{E}$ bonds $(\mathrm{E}=\mathrm{O}, \mathrm{S}$, Se, Te). However, the first examples of germacarbonyl compounds synthesized under ambient conditions by taking advantage of dipyrromethene ligand stabilization are detailed here; the isolated compounds are germanones 3-4, germacarboxylic acids 6-7, germaesters 9-10, and germaamides 12-13 with $\mathrm{Ge}=\mathrm{E}$ bonds $(\mathrm{E}=\mathrm{S}$, $\mathrm{Se})$. The germaamides $\mathbf{1 2 - 1 3}$ can react under atmospheric conditions with copper(I) halides offering air and water stable monomeric 1415 and dimeric 16-19 copper (I) complexes (halide $=\mathrm{Cl}, \mathrm{Br}, \mathrm{I}$ ). Apart from just binding, selectivity was also observed; thiogermaamide 12 and selenogermaamide 13 bind $\mathrm{CuCl}$ and $\mathrm{CuBr}$, respectively, when treated with a mixture of copper(I) halides.

\section{Introduction}

Inspired by the variety and usefulness of carbonyl compounds, such as aldehydes, ketones, amides, esters, carboxylic acids, acid halides, and acid anhydrides in organic chemistry, the synthesis of their heavier analogs constitutes an essential aspect of the modern main group chemistry. ${ }^{1-9}$ Thermodynamic and kinetic stabilizations are essential for isolating these compounds in a stable form; however, this stability is only under an inert atmosphere. ${ }^{1-9}$ Examples of heavy ketones are shown in (Chart 1). ${ }^{10-17}$ Silanone $\mathbf{i}$ and germanones ii-iii [ $L L^{\prime} M=O$ ] were isolated through the reaction of the corresponding NHC-silylene and germylene adducts [ $\left.\mathrm{LL}^{\prime} \mathrm{M}\right]$ with $\mathrm{N}_{2} \mathrm{O}$, respectively (Chart 1) $\left(\mathrm{L}=\left[\mathrm{CH}\left\{\left(\mathrm{C}=\mathrm{CH}_{2}\right)(\mathrm{CMe})(\mathrm{NAr})_{2}\right\}\right], \mathrm{L}^{\prime}=\left[\{(\mathrm{Me}) \mathrm{CN}(\mathrm{R})\}_{2} \mathrm{C}\right] ; \mathrm{Ar}=\right.$ 2,6-i $\left.\mathrm{Pr}_{2} \mathrm{C}_{6} \mathrm{H}_{3} ; \mathrm{M}=\mathrm{Si} ; \mathrm{R}=\mathrm{Me}(\mathrm{i}) ; \mathrm{M}=\mathrm{Ge} ; \mathrm{R}=\mathrm{Me}(\mathrm{ii}),{ }^{\mathrm{P}} \mathrm{Pr}(\mathrm{iii})\right) .{ }^{10-11}$ The reaction of pentacoordinate silane $\left[\mathrm{C}_{11} \mathrm{H}_{8} \mathrm{~N}\left(\mathrm{Me}_{2}\right) \mathrm{SiH}_{2} \mathrm{Ph}\right]$ with elemental sulfur and selenium resulted in silanethione and silaneselenone [( $\left.\mathrm{C}_{11} \mathrm{H}_{8} \mathrm{~N}\left(\mathrm{Me}_{2}\right) \mathrm{Si}(\mathrm{E}) \mathrm{Ph}\right) ; \mathrm{E}=\mathrm{S}$ (iv) and $\left.\mathrm{Se}(\mathbf{v})\right]$ (Chart 1). ${ }^{12}$ The desulfurization and deselenation of tetrathiogermolane and tetraselenogermolane ([Tbt(Tip)Ge(E) $\left.)_{4}\right] ; E=S$ and Se), gave germanethione and germaneselenone [Tbt(Tip)Ge=E; E = S (vi) and

Department of Chemistry, Indian Institute of Technology Delhi, Hauz Khas, New Delhi 110 016, India. E-mail: sisn@chemistry.iitd.ac.in

†Electronic supplementary information (ESI) available: Experimental section, molecular structure determination of compounds 2-4, 9, 11-14, 16-17, and 19 (PDF). CIFs for compounds 2-4, 9, 11-14, 16-17, and 19, are deposited with the Cambridge Structural Database (CSD); CCDC 2116996 (2), 2116997 (3), 2116998 (4), 2117002 (9), 2116999 (11), 2117005 (12), 2117004 (13), 2117001 (14), 2117000 (16), 2117006 (17), and 2117003 (19). These data can be obtained free of cost from CCDC center using link, https://www.ccdc.cam.ac.uk/.

Se (vii)], respectively (Chart 1). ${ }^{13-14}$ Germatellurones ([Tbt(R)Ge(Te)]; $\mathrm{R}=\operatorname{Tip}(\mathbf{v i i i )}$, Dis (ix)) were synthesized by the oxidation of the corresponding kinetically stabilized germylenes ([Tbt(R)Ge]; R = Tip and Dis) with elemental tellurium (Chart 1). ${ }^{15}$ The desulfurization of the tetrathiostannolanes $\left[\mathrm{Tbt}(\operatorname{Ditp}) \mathrm{Sn}(\mathrm{S})_{4}\right]$ by $\mathrm{PPh}_{3}$ afforded stannanethione ([Tbt(Ditp)Sn=S]) $\quad(\mathbf{x}) \cdot{ }^{16} \quad$ Stannaneselenone and stannanetellurone $\left(\left[\mathrm{L}_{2} \mathrm{Sn}=\mathrm{E}\right] ; \mathrm{E}=\mathrm{Se}(\mathbf{x i}), \mathrm{E}=\mathrm{Te}(\mathbf{x i i})\right)$ were isolated through the reaction of alkyl stannylene $\left[\mathrm{L}_{2} \mathrm{Sn}\right]$ with elemental selenium and tellurium $\left(\mathrm{L}=\mathrm{CH}\left(\mathrm{SiMe}_{3}\right) \mathrm{C}_{9} \mathrm{H}_{6} \mathrm{~N}-8\right)$ (Chart 1). ${ }^{17}$ These seminal works have spurred interest in heavy carbonyl compounds; the current literature has a variety of them synthesized and studied. ${ }^{18-69}$ However, there is no example of a heavy carbonyl compound that is stable in air and water to the best of our knowledge. With an object to develop the air and water stable lowvalent main group chemistry, we were looking at the possibility of making air and water stable heavy carbonyl compounds. Overcoming various challenges, we successfully isolated air and water stable germacarbonyl compounds with $\mathrm{Ge}=\mathrm{E}$ bonds $(\mathrm{E}=\mathrm{S}$, Se). Consequently, the synthesis of the first examples of air and water stable germanones (DPMGe(E)Ph; E = S (3), Se (4)), germacarboxylic

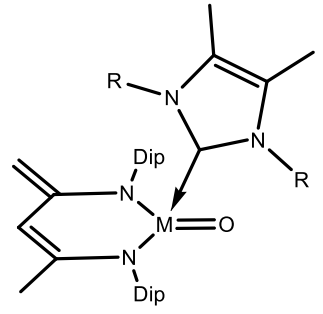

$M=S i: R=M e(i)$

$M=G e: R=M e(i i), R={ }^{i} \operatorname{Pr}($ iii)

Dip $=2,6-{ }^{i} \mathrm{Pr}_{2} \mathrm{C}_{6} \mathrm{H}_{3}$

(Driess)

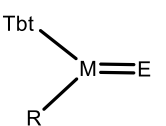

$M=G e: R=T i p ; E=S(v i)$, Se (vii), Te (viii) $M=S n: R=$ Ditp; $E=S(\mathbf{x})$

$\mathrm{Tbt}=2,4,6-\left(\mathrm{CH}\left(\mathrm{SiMe}_{3}\right)_{2}\right)_{3} \mathrm{C}_{6} \mathrm{H}_{2}$

Tip $=2,4,6-\left(\mathrm{CHMe}_{2}\right)_{3} \mathrm{C}_{6} \mathrm{H}_{2}$

Ditp $=2,6-\left(2-{ }^{-} \mathrm{PrC}_{6} \mathrm{H}_{4}\right)_{2} \mathrm{C}_{6} \mathrm{H}_{3}$

Dis $=\mathrm{CH}\left(\mathrm{SiMe}_{3}\right)_{2}$

(Okazaki)

Chart 1. Examples of heavy ketones
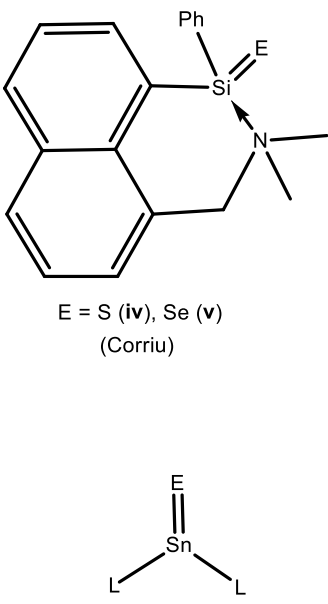

$E=\operatorname{Se}(\mathbf{x i}), \mathrm{Te}$ (xii)

$\mathrm{L}=\mathrm{CH}\left(\mathrm{SiMe}_{3}\right) \mathrm{C}_{9} \mathrm{H}_{6} \mathrm{~N}-8$

(Leung) 
acids (DPMGe(E)OH; E = S (6), Se (7)), germaesters (DPMGe(E)OEt; E = S (9), Se (10)), and germaamides (DPMGe(E)N(TMS) ${ }_{2} ; \mathrm{E}=\mathrm{S}(\mathbf{1 2})$, Se (13)) are reported (DPM = dipyrrinate). Further described are the reactions of compounds $\mathbf{1 2}$ and $\mathbf{1 3}$ with copper(I) halides $(\mathrm{X}=\mathrm{Cl}, \mathrm{Br}$, I) to afford germaamide stabilized copper(I) complexes $\left(\mathrm{DPMGe}(\mathrm{E}) \mathrm{N}(\mathrm{TMS})_{2} \rightarrow \mathrm{CuCl}\right) \quad(\mathrm{E}=\mathrm{S}$ (14), Se (15)) and [(DPMGe(E) $\left.\left(\mathrm{N}(\mathrm{TMS})_{2}\right) \rightarrow \mathrm{CuX}\right]_{2}(\mathrm{E}=\mathrm{S} ; \mathrm{X}=\mathrm{Br}(\mathbf{1 6}), \mathrm{I}(\mathbf{1 7})$ and $\mathrm{E}=\mathrm{Se} ; \mathrm{X}=$ $\mathrm{Br}(\mathbf{1 8}), \mathrm{I}(\mathbf{1 9}))$ that are air and water stable. All the reactions offering these copper complexes were conducted under ambient conditions using non-dried solvents. Intriguing is the discovery of selectivity involved in the reactions of compounds $\mathbf{1 2}$ and $\mathbf{1 3}$ with a mixture of copper $(\mathrm{I})$ halides $(\mathrm{X}=\mathrm{Cl}, \mathrm{Br}, \mathrm{I})$; the former and latter binds only with $\mathrm{CuCl}$ and $\mathrm{CuBr}$, respectively.

\section{Synthesis and Spectra:}

With the knowledge of dipyrrinate stabilized monochlorogermylenes being air and water stable, ${ }^{70,71}$ we studied the utility of DPMGeCl (1) to afford air and water stable germaacid chlorides. The reactions of compound $\mathbf{1}$ were carried out with elemental sulphur and selenium in toluene for $12 \mathrm{~h}$ at room temperature; the result was no reaction between the reagents and even excessive amounts of chalcogens offering no help. When the reactions between compound 1 and excess of chalcogens were carried out at high temperature $\left(60^{\circ} \mathrm{C}\right)$ for $12 \mathrm{~h}$, desired germaacyl chlorides were formed along with an unidentified side product. However, efforts to separate this product were not fruitful until now. In light of this, it was envisaged that replacing the chlorine of compound $\mathbf{1}$ with other functional groups may bring in clean reactions between germylenes and chalcogens. Phenyl germylene DPMGePh (2) was synthesized in 95\% yield as air and water stable solid (vide infra) through the reaction of germylene 1 with phenyl lithium at $-20^{\circ} \mathrm{C}$ in toluene for $12 \mathrm{~h}$. As the handling of phenyl lithium requires an inert atmosphere, phenyl germylene $\mathbf{2}$ was synthesized under a nitrogen atmosphere using a dried solvent. As anticipated, the reactions of compound $\mathbf{2}$ under ambient conditions with stoichiometric amounts of elemental sulphur and selenium occurred smoothly in toluene at room temperature for $1 \mathrm{~h}$ to afford germanethione DPMGe(S)Ph (3) and germaneselenone DPMGe(Se)Ph (4) in 95\% and 93\% yields (Scheme 1). THF and DCM as solvents instead of toluene did not offer germanones $\mathbf{3}$ and $\mathbf{4}$ cleanly. Attempts to isolate germatellurone through the reaction between phenyl germylene $\mathbf{2}$ and elemental tellurium did not succeed. Similarly, the reactions of compound $\mathbf{2}$ with nitrous oxide, $\mathrm{N}$-(methyl)morpholine- $\mathrm{N}$-oxide, and pyridine $\mathrm{N}$-oxide also failed to offer germanone with $\mathrm{Ge}=\mathrm{O}$ bond.
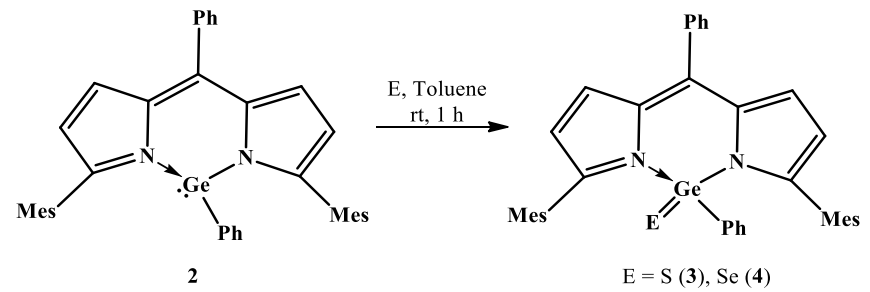

Scheme 1. Synthesis of germanones 3-4
The synthesis of thio- and selenogermaaldehydes was tried; this requires a germylene hydride precursor. The reaction of monochlorogermylene $\mathbf{1}$ with various hydride sources, such as $\mathrm{NaBH}_{4}$, $\mathrm{LiAlH}_{4}$, K-selectride, and $\mathrm{NaH}$, did not result in the anticipated germylene hydride. The reactions of germylene hydroxide $\mathrm{DPMGeOH}^{70}$ (5) with elemental sulphur and selenium powder at room temperature in toluene were checked to isolate germacarboxylic acids. These reactions offered thiogermacarboxylic acid DPMGe(S)OH (6) and selenogermacarboxylic acid DPMGe(Se)OH (7) in 95\% and 96\% yields after 20 min (Scheme 2). Similarly, under the same reaction conditions, thiogermaester DPMGe(S)OEt (9) and selenogermaester DPMGe(Se)OEt (10) were also synthesized from germylene ethoxide DPMGeOEt ${ }^{70}$ (8) in $97 \%$ and $96 \%$ yields (Scheme 2 ).

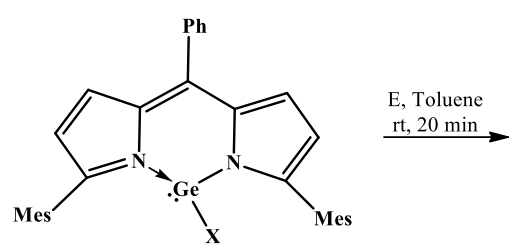

$\mathrm{X}=\mathrm{OH}(\mathbf{5})$, OEt $(\mathbf{8})$

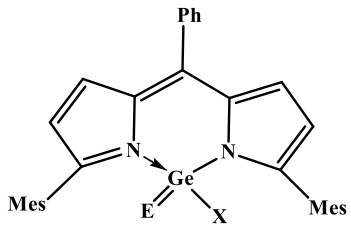

$\mathrm{X}=\mathrm{OH} ; \mathrm{E}=\mathrm{S}(\mathbf{6}), \mathrm{Se}(7)$ $\mathrm{X}=\mathrm{OEt} ; \mathrm{E}=\mathrm{S}(\mathbf{9}), \mathrm{Se}(\mathbf{1 0})$
Scheme 2. Synthesis of germacarboxylic acids 6-7, and germaesters $\mathbf{9 - 1 0}$

Finally, the synthesis of germaamides was tried; the required aminogermylene 11 was obtained in $97 \%$ yield through the reaction of monochlorogermylene 1 with $\operatorname{LiN}(\mathrm{TMS})_{2}$ at $-20{ }^{\circ} \mathrm{C}$ for $12 \mathrm{~h}$ in toluene. The reactions of aminogermylene $\mathbf{1 1}$ with excess amounts of elemental sulphur and selenium in toluene at $60{ }^{\circ} \mathrm{C}$ for $12 \mathrm{~h}$ resulted in thiogermaamide DPMGe(S) $\mathrm{N}(\mathrm{TMS})_{2} \quad$ (12) and selenogermaamide DPMGe(Se)N(TMS) 2 (13) in 95\% and $94 \%$ yields (Scheme 3). The steric crowding due to the bulky $\mathrm{N}(\mathrm{TMS})_{2}$ group of germylene $\mathbf{1 1}$ may justify the high-temperature requirement to form germaamides $\mathbf{1 2}$ and $\mathbf{1 3}$.

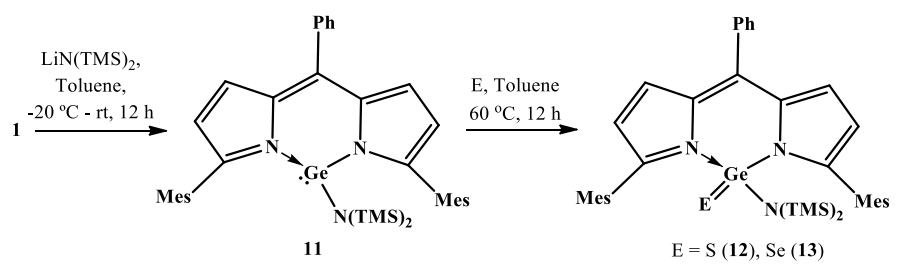

Scheme 3. Synthesis of germaamine $\mathbf{1 1}$ and germaamides 12-13

Compounds 3-4, 6-7, 9-10, and $\mathbf{1 2 - 1 3}$ are the first examples of air and water stable heavy carbonyl compounds (Table 1); this stability reveals the ability of bulky DPM ligands to protect the polar $\mathrm{Ge}=\mathrm{E}$ bonds $(E=S$, Se). The air and water stability of these germacarbonyl compounds were monitored by ${ }^{1} \mathrm{H}$ NMR spectroscopy (see Figures S7-8, S11-12, S16, S19-20, S24-25, S28-29, S38-39, and S43-44). The air stability was checked for up to 10 days and found that all the compounds were stable. Concerning the water stability, the germacarbonyl compounds $\mathbf{3}, \mathbf{4}, \mathbf{9}, \mathbf{1 0}, \mathbf{1 2}$, and $\mathbf{1 3}$ are stable in water for $2,4,3,5,2$, and 5 days, respectively (Table 1). The germacarboxylic acids displayed poor water stability; the 
selenogermacarboxylic acid 7 is stable for $6 \mathrm{~h}$, while the thiogermacarboxylic acid 6 is not stable and produces DPMH (2\%) just after $10 \mathrm{~min}$ of water addition. Among germanones, germaesters, and germaamides, germaesters $\mathbf{9 - 1 0}$ and germaamides 12-13 show more water stability than germanones 3-4. This stability may be attributed to the electron-donating OEt and $\mathrm{N}(\mathrm{TMS})_{2}$ moieties of germaesters $\mathbf{9 - 1 0}$ and germaamides $\mathbf{1 2 - 1 3}$, enhancing electron density on the germanium centers and reducing the polarity of the formal $\mathrm{Ge}=\mathrm{E}$ bonds, respectively (Table 1). Moreover, selenogermacarbonyl compounds displayed better stability than the corresponding thiogermacarbonyl compounds, perhaps due to the stronger $\mathrm{Ge}=\mathrm{Se}$ bond in selenogermacarbonyl compounds than the $\mathrm{Ge}=\mathrm{S}$ bond in thiogermacarbonyl compounds (Table 1).51,54,56-57

Table 1. Air and water stability of germacarbonyl compounds with $\mathrm{Ge}=\mathrm{E}$ bonds $(\mathrm{E}=\mathrm{S} / \mathrm{Se})$

\begin{tabular}{|c|c|c|}
\hline Compound & $\begin{array}{l}\text { Air Stability } \\
\text { (Days) }\end{array}$ & $\begin{array}{l}\text { Water Stability } \\
\text { (Day(s)) }\end{array}$ \\
\hline DPMGe(S)Ph (3) & 10 & 2 \\
\hline DPMGe(Se)Ph (4) & 10 & 4 \\
\hline DPMGe(S)OH (6) & 10 & Not Stable \\
\hline DPMGe(Se)OH (7) & 10 & 0.25 \\
\hline DPMGe(S)OEt (9) & 10 & 3 \\
\hline DPMGe(Se)OEt (10) & 10 & 5 \\
\hline DPMGe(S)N(TMS) 2 (12) & 10 & 2 \\
\hline $\mathrm{DPMGe}(\mathrm{Se}) \mathrm{N}(\mathrm{TMS})_{2}$ (13) & 10 & 5 \\
\hline
\end{tabular}

${ }^{a}$ Air stability was checked for up to $10 \mathrm{~d}$ only; therefore, they may be stable for a considerable period beyond this $10 \mathrm{~d}$. For example, our experience with compound $\mathbf{1 3}$ reveals that it did not start to decompose even after one month of storage under ambient conditions. ${ }^{\text {b}}$ Formation of $1-2 \%$ of DPMH was seen after the specified period of water stability.

The successful isolation of air and water stable germacarbonyl compounds prompted us to examine their reactivity at ambient conditions. Considering the presence of $\sigma$-donor chalcogen atoms (S, $\mathrm{Se}$ ) in the germacarbonyl compounds 3-4, 6-7, 9-10, and 12-13, we started to scrutinize their ability to stabilize transition metal complexes. ${ }^{46,52-53,73-74}$ The reactions of compounds 3-4, 6-7, and 9-10 with excess amounts of copper $(\mathrm{I})$ halides $\mathrm{Cu}(\mathrm{I}) \mathrm{X}$ at room temperature for $1 \mathrm{~h}$ did not result in the desired complexes; the reactants remained unreacted $(\mathrm{X}=\mathrm{Cl}, \mathrm{I})$. However, the reaction of thiogermaamide DPMGe(S)N(TMS) ${ }_{2}$ (12) with an equimolar amount of $\mathrm{Cu}(\mathrm{I}) \mathrm{Cl}$ at room temperature in toluene for $30 \mathrm{~min}$ resulted in monomeric thiogermaamide stabilized copper(I) chloride complex [DPMGe(S)N(TMS) $)_{2} \rightarrow \mathrm{CuCl}$ (14) in 89\% yield (Scheme 4). In contrast, its reactions with other copper(I) halides $(\mathrm{Cu}(\mathrm{I}) \mathrm{Br}$ and $\mathrm{Cu}(\mathrm{I}) \mathrm{I})$ in toluene at room temperature for $30 \mathrm{~min}$ resulted in dimeric thiogermaamide stabilized copper(I) complexes
[DPMGe(S)N(TMS) $\left.)_{2} \rightarrow \mathrm{CuX}\right]_{2}$ with $\mathrm{Cu}_{2} \mathrm{X}_{2}$ core in $94 \%$ and $90 \%$ yields, respectively ( $X=B r$ (16), I (17)) (Scheme 4). Similarly, equimolar reactions of selenogermaamide $\mathrm{DPMGe}(\mathrm{Se}) \mathrm{N}(\mathrm{TMS})_{2}(\mathbf{1 3})$ with $\mathrm{Cu}(\mathrm{I}) \mathrm{Cl}$ and $\mathrm{Cu}(\mathrm{I}) \mathrm{X}(\mathrm{X}=\mathrm{Br}, \mathrm{I})$ in toluene for $30 \mathrm{~min}$ at room temperature afforded monomeric and dimeric selenogermaamide stabilized copper(I) halides complexes [DPMGe(Se)N(TMS) ${ }_{2} \rightarrow \mathrm{CuCl}$ ] $(15$; yield 95\%) and [DPMGe(Se)N(TMS) $\left.)_{2} \rightarrow \mathrm{CuX}\right]_{2},(\mathrm{X}=\mathrm{Br}$ (18; yield 92\%), I (19; yield 94\%)), respectively (Scheme 4). The thiogermaamide and selenogermaamide stabilized monomeric $(\mathbf{1 4}, \mathbf{1 5})$ and dimeric copper complexes $(\mathbf{1 6 - 1 7}, \mathbf{1 8 - 1 9})$ represent the first examples of germacarbonyl compound stabilized copper(I) halide complexes.

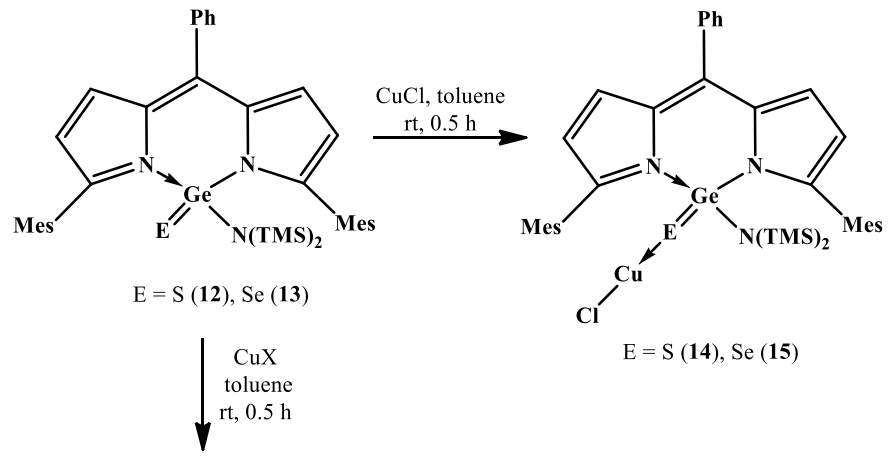

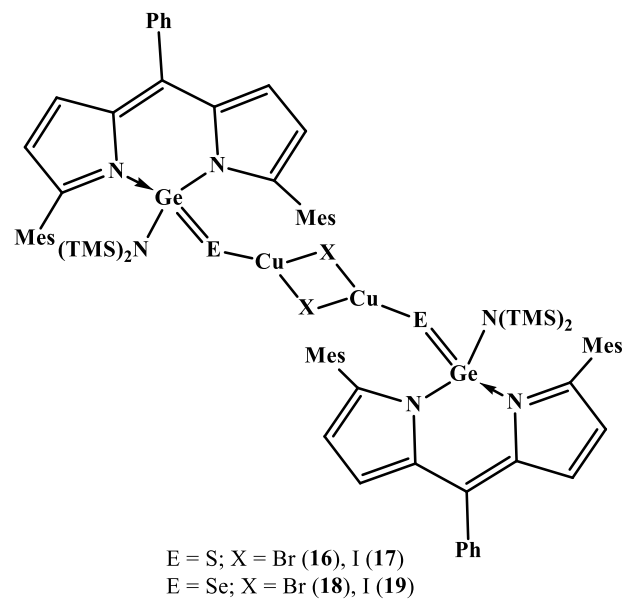

Scheme 4. Synthesis of germaamide stabilized monomeric and dimeric copper(I) complexes 14-19

Germaamides, apart from reacting independently with $\operatorname{CuX~}(X=\mathrm{Cl}$, $\mathrm{Br}, \mathrm{I})$, showed a novel aspect of selective binding towards a particular copper halide when a mixture of copper halides is present (see SI for details). The reaction of thiogermaamide $\mathbf{1 2}$ with an equimolar mixture of $\mathrm{CuX}(\mathrm{X}=\mathrm{Cl}, \mathrm{Br}, \mathrm{I})$ in toluene for $15 \mathrm{~min}$ at room temperature gave exclusively compound $\mathbf{1 4}$ by reacting with $\mathrm{CuCl}$ only (see Scheme S1). In contrast, selenogermaamide $\mathbf{1 3}$ under the same reaction conditions reacted selectively with $\mathrm{CuBr}$ and gave compound 18 (see Scheme S2). Even when thiogermaamide 12 was reacted with a mixture $\mathrm{CuX}$ containing one equiv of copper chloride and an excess of copper bromide and copper iodide (three equivalents each), it reacted only with copper chloride affording copper chloride complex $\mathbf{1 4}$ (see Scheme S3). The same was the result for selenogermaamide 13; its reaction with a mixture of $\mathrm{CuX}$ 
salts containing copper chloride, copper bromide, and copper iodide in a ratio of 3:1:3, gave selectively copper bromide complex 18 (see Scheme S4). Further, germaamides $\mathbf{1 2}$ and $\mathbf{1 3}$ did not react with $\mathrm{AgX}$ $(\mathrm{X}=\mathrm{Cl}, \mathrm{Br}, \mathrm{I})$ and $\mathrm{AuX}(\mathrm{Cl}, \mathrm{I})$.

Interestingly, compounds 14-19 are the first examples of germacarbonyl compound stabilized transition metal complexes that are air and water stable. This feat was achievable due to the favorable steric protection and electronic stabilization offered by the bulky dipyrrinate ligand to the $\mathrm{Ge}=\mathrm{E} \rightarrow \mathrm{Cu}$ moieties in these complexes. Akin to the methodology followed with germacarbonyl compounds, the stability of these copper(I) complexes were studied using ${ }^{1} \mathrm{H}$ NMR spectroscopy (see Figures S49-50, S54-55, 60-61, 65$66,570-71$, and S76-77). The complexes were stable in the air up to the monitored period of 10 days. Regarding the water stability, thiogermaamide stabilized copper(I) complexes 14, 16, and 17 were stable for 3 h, 1 day, and 3 days, respectively. It is explicit from the data that ongoing from chloride to iodide, the water stability increases. The same trend is seen for the selenogermaamide stabilized copper(I) complexes 15, 18, and 19; they were stable for 3 h, $12 \mathrm{~h}$, and 2 days, respectively (Table 2). An interesting trend for the dimeric copper complexes is that thiogermaamide stabilized compounds display better stability than the selenogermaamide stabilized compounds.

Table 2. Air and water stability of germaamide stabilized copper(I) complexes 14-19

\begin{tabular}{|c|c|c|}
\hline Compound & $\begin{array}{c}\text { Air } \\
\text { Stability } \\
\text { (Days) }\end{array}$ & $\begin{array}{c}\text { Water } \\
\text { Stability } \\
\text { (Day(s)) }\end{array}$ \\
\hline $\begin{array}{c}{\left[\left(\mathrm{DPMGe}(\mathrm{S}) \mathrm{N}(\mathrm{TMS})_{2} \rightarrow \mathrm{CuCl}\right]\right.} \\
(\mathbf{1 4})\end{array}$ & 10 & 0.125 \\
\hline $\begin{array}{c}{\left[\left(\mathrm{DPMGe}(\mathrm{S}) \mathrm{N}(\mathrm{TMS})_{2} \rightarrow \mathrm{CuBr}\right]_{2}\right.} \\
(\mathbf{1 6})\end{array}$ & 10 & 1 \\
\hline $\begin{array}{c}{\left[\left(\mathrm{DPMGe}(\mathrm{S}) \mathrm{N}(\mathrm{TMS})_{2} \rightarrow \mathrm{Cul}\right]_{2}\right.} \\
(\mathbf{1 7})\end{array}$ & 10 & 3 \\
\hline $\begin{array}{c}{\left[\left(\mathrm{DPMGe}(\mathrm{Se}) \mathrm{N}(\mathrm{TMS})_{2} \rightarrow \mathrm{CuCl}\right]\right.} \\
(\mathbf{1 5})\end{array}$ & 10 & 0.125 \\
\hline $\begin{array}{c}{\left[\left(\mathrm{DPMGe}(\mathrm{Se}) \mathrm{N}(\mathrm{TMS})_{2} \rightarrow \mathrm{CuBr}\right]_{2}\right.} \\
(\mathbf{1 8})\end{array}$ & 10 & 0.50 \\
\hline $\begin{array}{c}{\left[\left(\mathrm{DPMGe}(\mathrm{Se}) \mathrm{N}(\mathrm{TMS})_{2} \rightarrow \mathrm{Cul}\right]_{2}\right.} \\
(\mathbf{1 9})\end{array}$ & 10 & 2 \\
\hline
\end{tabular}

aAir stability was checked for up to $10 \mathrm{~d}$ only; therefore, they may be stable for a considerable period beyond this $10 \mathrm{~d}$. For example, our experience with compound $\mathbf{1 6}$ reveals that it did not start to decompose even after one month of storage under ambient conditions. ${ }^{b}$ Formation of 1-2\% of DPMH was seen after the specified period of water stability.

The germanones 3-4, germacarboxylic acids 6-7, germaesters 9-10, and germaamides $\mathbf{1 2 - 1 3}$ are freely soluble in toluene, tetrahydrofuran, dichloromethane, and chloroform. The germaamide stabilized copper(I) complexes 14-19 have limited solubility in tetrahydrofuran and toluene. The thiogermaamide stabilized copper(I) complexes 14, 16, and 17 are also soluble in dichloromethane; however, their selenium analogs 15, 18, and 19 are only partially soluble. The newly synthesized compounds 2-4, 67, and 9-19 were characterized in the solution state through multinuclear NMR spectroscopic techniques $\left({ }^{1} \mathrm{H},{ }^{13} \mathrm{C},{ }^{29} \mathrm{Si},{ }^{77} \mathrm{Se}\right)$. In the ${ }^{1} \mathrm{H}$ NMR spectra of germanones 3-4, germacarboxylic acids 6-7, germaesters $\mathbf{9 - 1 0}$, and germaamides $\mathbf{1 2 - 1 3}$, all the resonances are slightly downfield shifted compared to their germylene precursors $\mathbf{1}$, $\mathbf{5}, \mathbf{8}$, and $\mathbf{1 1}$, respectively (see the $\mathrm{SI}$ for details). This shift is due to the germanium atoms' formal oxidation state increase from +2 (in compounds $\mathbf{1}, \mathbf{5}, \mathbf{8}$, and $\mathbf{1 1}$ ) to +4 (in compounds 3-4, 6-7, 9-10, and 12-13) owing to their attachment to electronegative sulphur/selenium atoms.

Almost all the resonances of thio- and selenogermaamide stabilized copper(I) complexes 14, 16, 17 and 15, 18, 19 showed further downfield shifts to those of thiogermaamide 12 and selenogermaamide 13 , respectively (see the $\mathrm{SI}$ for details). This effect is due to the donation of lone pair of electrons from sulphur/selenium atom of the $\mathrm{Ge}=\mathrm{E}$ bond to the copper atom $(\mathrm{E}=$ $\mathrm{S} / \mathrm{Se}$ ). In the ${ }^{13} \mathrm{C}$ NMR spectra of compounds 2-4, 6-7, and 9-19, the expected number of signals (ranging from 13 to 21 depending on the group attached to the germanium atom) were seen. In the ${ }^{29} \mathrm{Si} N \mathrm{NR}$ spectra of compounds 11-19, except germylene $\mathbf{1 1}$ that gave two resonances at -3 and $2 \mathrm{ppm}$, all the other compounds showed a signal

Table 3. ${ }^{77} \mathrm{Se}$ NMR spectroscopic data of germaselenocarbonyl compounds containing $\mathrm{Ge}=\mathrm{Se}$ bonds.

\begin{tabular}{|c|c|c|}
\hline Compound & $\begin{array}{c}{ }^{77} \mathrm{Se} \\
\text { Resonance, } \\
\delta \text { in ppm }\end{array}$ & Reference \\
\hline [Tbt(Tip)Ge(Se)] (vii) & 940.6 & 14 \\
\hline$\left[\left({ }^{t} \mathrm{Bu}\right)_{2} \mathrm{ATIGe}(\mathrm{Se}) \mathrm{Ph}\right](\mathbf{x i i i})$ & -216.97 & 53 \\
\hline $\begin{array}{c}{[\{\mathrm{HC}(\mathrm{CMe})(\mathrm{N}(2,6-} \\
\left.\left.\left.\left.{ }^{i} \mathrm{Pr}_{2} \mathrm{C}_{6} \mathrm{H}_{3}\right)\right)_{2}\right\} \mathrm{Ge}(\mathrm{Se}) \mathrm{OH}\right](\text { xiv })\end{array}$ & -439.8 & 60 \\
\hline $\begin{array}{c}{\left[(\mathrm{R})_{2} \mathrm{~A} T I G e(\mathrm{Se}) \mathrm{O}^{t} \mathrm{Bu}\right]\left(\mathrm{R}={ }^{t} \mathrm{Bu}(\mathbf{x v}),\right.} \\
{ }^{i} \mathrm{Bu}(\mathbf{x v i})\end{array}$ & $\begin{array}{l}-77.76(x v), \\
-285.10(x v i)\end{array}$ & 57 \\
\hline $\begin{array}{c}{\left[(\mathrm{R})_{2} \mathrm{ATIGe}(\mathrm{Se}) \mathrm{N}(\mathrm{TMS})_{2}\right]\left(\mathrm{R}={ }^{t} \mathrm{Bu}\right.} \\
\left(\text { xvii) }{ }^{\mathrm{i}} \mathrm{Bu}(\mathbf{x v i i i})\right)\end{array}$ & $\begin{array}{c}-36.76 \text { (xvii), } \\
-183.31 \\
\text { (xviii) }\end{array}$ & 48 \\
\hline [DPMGe(Se)Ph] (4) & -386 & This work \\
\hline [DPMGe(Se)OH] (7) & -340 & This work \\
\hline [DPMGe(Se)OEt] (10) & -379 & This work \\
\hline$\left[\mathrm{DPMGe}(\mathrm{Se}) \mathrm{N}(\mathrm{TMS})_{2}\right](\mathbf{1 3})$ & -178 & This work \\
\hline$\left[\left(\mathrm{DPMGe}(\mathrm{Se})\left(\mathrm{N}(\mathrm{TMS})_{2}\right) \rightarrow \mathrm{CuCl}\right](\mathbf{1 5})\right.$ & -237 & This work \\
\hline$\left[\left(\mathrm{DPMGe}(\mathrm{Se})\left(\mathrm{N}(\mathrm{TMS})_{2}\right) \rightarrow \mathrm{CuBr}\right]_{2}(\mathbf{1 8})\right.$ & -228 & This work \\
\hline$\left[\left(\mathrm{DPMGe}(\mathrm{Se})\left(\mathrm{N}(\mathrm{TMS})_{2}\right) \rightarrow \mathrm{Cul}\right]_{2}(19)\right.$ & -235 & This work \\
\hline
\end{tabular}


close to $-22 \mathrm{ppm}$; this data confirms the presence of trimethylsilyl group. In the ${ }^{77}$ Se NMR spectroscopic studies of selenogermanone 4 , selenocarboyxlic acid $\mathbf{7}$, and selenoester $\mathbf{1 0}$, the resonances for the selenium atoms were seen at $-386 \mathrm{ppm},-340 \mathrm{ppm}$, and $-379 \mathrm{ppm}$, respectively. For the selenogermaamide 13, a signal was observed at -178 ppm; its copper(I) complexes 15, 18, and 19 showed upfield shifted resonances at $-237,-228$, and $-235 \mathrm{ppm}$, respectively (see the $\mathrm{SI}$ for details). As the selenium resonances of these compounds are in between the resonances of $\left(\mathrm{H}_{3} \mathrm{Ge}\right)_{2} \mathrm{Se}(-612 \mathrm{ppm})$ with a $\mathrm{Ge}-\mathrm{Se}$ single bond ${ }^{73}$ and [Tbt(Tip)Ge(Se)] (vii) (940.6 ppm) ${ }^{14}$ having an electronically unperturbed $\mathrm{Ge}=\mathrm{Se}$ double bond, the $\mathrm{Ge}=\mathrm{Se}$ bonds in them should be polarized with partial positive and negative charges on the germanium and selenium atoms, respectively (Table 3 ). Despite such polarization, it is interesting to see them as air and water stable compounds, which should be attributed to the kinetic and thermodynamic stabilizations bestowed by the bulky DPM ligands.

\section{X-ray Crystal Structures of Compounds 2-4, 9, 11-} 14, 16-17, and 19.

Molecular structures of germylenes (2 and 11), germacarbonyl compounds $(3,4,9,12$, and 13$)$, and metal complexes $(14,16,17$, and 19) were confirmed by single-crystal $X$-ray diffraction analysis. Compounds $\mathbf{2}, \mathbf{1 7}$, and 19 crystallized in the monoclinic space group $P 2_{1} / c$, while compounds $\mathbf{3}, \mathbf{4}, \mathbf{9}$, and $\mathbf{1 1}$ crystallized in the monoclinic space group $P 2_{1} / n$. Compounds $\mathbf{1 2 - 1 4}$ and 16 crystallized in the triclinic space group $P$-1. The germanium atom of the germylenes 2 and $\mathbf{1 1}$ is tricoordinate with two nitrogen atoms of the DPM ligands and one $X$ atom of the functional group $(X=C 2, N$ 11). In compounds $3,4,9,12-14,16,17$, and 19, the germanium atom(s) has(have) distorted tetrahedral geometry with two DPM ligand nitrogens, one double-bonded sulphur/selenium, and one $X$ atom of the functional group $(X=C(3-4), O(9)$, and $N(12-14,16,17$, and 19) (see Figures S82-S92). The average length of $\mathrm{Ge}-\mathrm{N}_{\text {ligand }}$ bonds in compounds 3

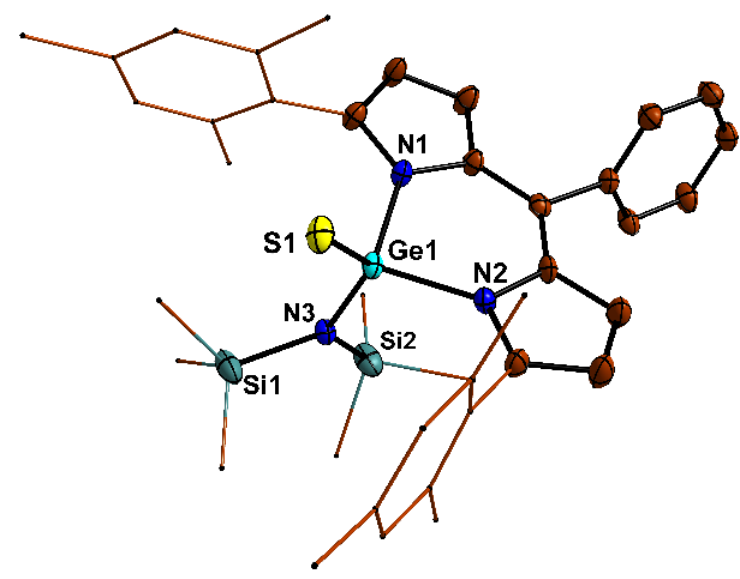

Figure 1. Molecular structure of thiogermaamide $\mathbf{1 2}$ with thermal ellipsoids at the $40 \%$ probability level. All hydrogen atoms are omitted for clarity. Selected bond lengths (Å) and angles (deg): $\mathrm{Ge}(1)-\mathrm{S}(1)$ 2.062(1), Ge(1)-N(1) 1.951(4), Ge(1)-N(2) 1.953(3), $\mathrm{Ge}(1)-\mathrm{N}(3) \quad 1.843(3) ; \quad \mathrm{N}(3)-\mathrm{Ge}(1)-\mathrm{N}(1) \quad 105.91(2), \quad \mathrm{N}(3)-\mathrm{Ge}(1)-\mathrm{N}(2) \quad 107.46(2)$, $\mathrm{N}(1)-\mathrm{Ge}(1)-\mathrm{N}(2)$ 92.75(2). Data collection temperature: $100 \mathrm{~K}$.
(1.945 $\AA$ ), $\mathbf{4}(1.944 \AA), \mathbf{1 2}(1.952 \AA)$, and $\mathbf{1 3}(1.952 \AA)$ are shorter than those in their precursors $\mathbf{2}(2.009 \AA)$ and $\mathbf{1 1}(2.033 \AA)$. Similarly, the Ge-X bond in compounds $3\left(1.928(6) \AA ; X=C_{P h}\right), 4(1.933(2) \AA ; X=$ $\left.\mathrm{C}_{\mathrm{Ph}}\right), 12\left(1.843(3) \AA \AA X=\mathrm{N}_{\mathrm{N}(\mathrm{TMS})_{2}}\right)$, and $13\left(1.837(7) \AA \AA X=\mathrm{N}_{\left.\mathrm{N}(\mathrm{TMS})_{2}\right)}\right)$ is also shorter compared to that in compounds $2\left(2.001(2) \AA ; X=C_{p h}\right)$ and $11\left(1.924(2) \AA ; X=N_{N(T M S)_{2}}\right)$. These effects are due to the higher

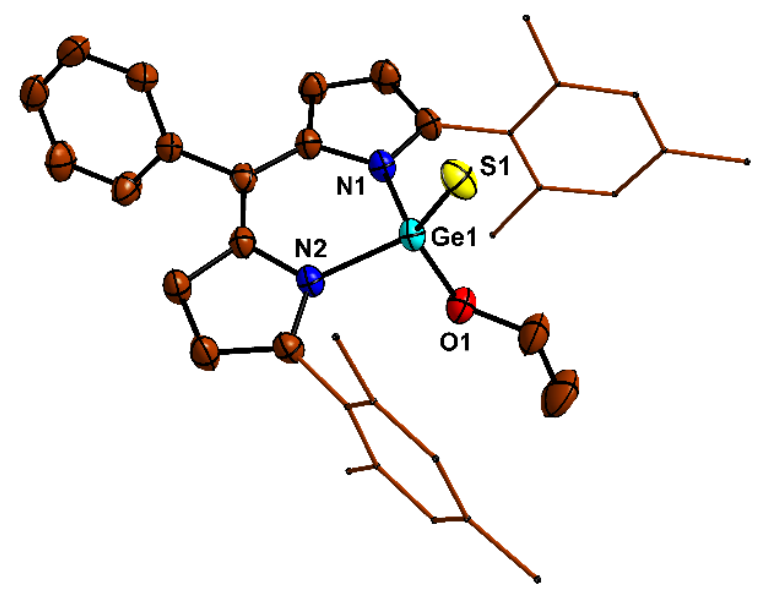

Figure 2. Molecular structure of thiogermaester 9 with thermal ellipsoids at the $30 \%$ probability level. All hydrogen atoms are omitted for clarity. Selected bond lengths $(\AA)$ and angles (deg): $\mathrm{Ge}(1)-\mathrm{S}(1)$ 2.058(5), $\mathrm{Ge}(1)-\mathrm{O}(1)$ 1.751(2), $\mathrm{Ge}(1)-\mathrm{N}(1)$ 1.914(2), $\mathrm{Ge}(1)-\mathrm{N}(2) \quad 1.915(2) ; \quad \mathrm{O}(1)-\mathrm{Ge}(1)-\mathrm{N}(1) \quad 102.74(6), \quad \mathrm{O}(1)-\mathrm{Ge}(1)-\mathrm{N}(2) \quad 100.60(7)$ $\mathrm{N}(1)-\mathrm{Ge}(1)-\mathrm{N}(2)$ 93.05(6). Data collection temperature: $273 \mathrm{~K}$.

electrophilicity of the germanium atom in compounds $\mathbf{3}, \mathbf{4}$, and $\mathbf{1 2 -}$ $\mathbf{1 3}$ than that in germylenes $\mathbf{2}$ and 11; the electrophilicity is increased by the electronegative chalcogen atom doubly bonded to germanium. The $\mathrm{Ge}=\mathrm{S}$ bond in thiogermanone $3(2.052(2) \AA)$, thiogermaester $9(2.058(5) \AA)$, and thiogermaamide 12 (2.062(1) $\AA$ ) are shorter than that in aminotroponimine ligand stabilized thiogermanone LGe(S)Ph (xix) $(2.102(7) \quad \AA$ ), 53 thiogermaester $\mathrm{LGe}(\mathrm{S}) \mathrm{O}^{t} \mathrm{Bu} \quad(\mathbf{x v i}) \quad(2.080(2) \quad \AA), 57 \quad$ and thiogermaamide $\mathrm{LGe}(\mathrm{S}) \mathrm{N}\left(\mathrm{SiMe}_{3}\right)_{2}$ (xviii) $\left(2.083(1) \AA ̊\right.$ ), respectively ${ }^{48}\left(\mathrm{~L}=\left({ }^{\mathrm{B}} \mathrm{Bu}\right)_{2} \mathrm{ATI} ; \mathrm{ATI}\right.$ $=$ aminotroponimine). Further, the $\mathrm{Ge}=\mathrm{S}$ bond of compound $\mathbf{3}$ is much shorter than the Ge-S single bond (2.239(1) $\AA)^{67}$ in compound $\left[\left\{(\mathrm{TMS}){ }_{2} \mathrm{C}(2-\mathrm{py})\right\}\{(\mathrm{TMS}) \mathrm{C}(2-\mathrm{py})\}\right] \mathrm{GeS}(\mathrm{TMS})$, and is slightly longer than the unperturbed $\mathrm{Ge}=\mathrm{S}$ bond $(2.049$ (3) $\AA$ ) in the kinetically stabilized thiogermanone $\mathrm{Tbt}(\mathrm{Tip}) \mathrm{Ge}=\mathrm{S}$ (vi). ${ }^{13}$ These comparisons may indicate that the polarization in the $\mathrm{Ge}=\mathrm{S}$ bond of compound $\mathbf{3}$ is in between that of compounds vi and xix. A similar trend was seen for the selenium analogs 4 and 13. The $\mathrm{Ge}=\mathrm{Se}$ bond of compounds 4 (2.195(3) A) and 13 (2.194(1) A) is shorter than that in ATI ligand stabilized selenogermanone (xiii) $(2.235(2) \quad \AA)^{53}$ and selenogermaamide (xvii) (2.222(1) $\AA$ ) ${ }^{48}$ respectively. The Ge=Se bond of compound $\mathbf{4}$ is much shorter than the Ge-Se single bond (2.433(1) $\AA$ ) in compound [Tbt(Mes)GeSe] $]_{2}$ and marginally longer than the $\mathrm{Ge}=\mathrm{Se}$ bond $2.180 \AA$ in kinetically stabilized selenogermanone [Tbt(Tip)Ge=Se] (vii). ${ }^{14}$

Due to the coordination of the sulfur atom of $\mathrm{Ge}=\mathrm{S}$ bond with Lewis acid $(\mathrm{CuCl} / \mathrm{CuBr} / \mathrm{Cul})$, the $\mathrm{Ge}=\mathrm{S}$ bond of thiogermaamide stabilized

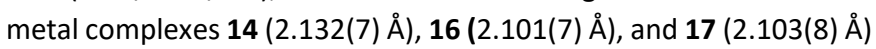


is elongated compared to that in thiogermaamide 12 (2.062(1) $\AA$ ) (see Figures $\mathrm{S} 87$ and S89-91). A similar trend is seen in the selenogermaamide stabilized copper complex 19; its $\mathrm{Ge}=\mathrm{Se}$ bond $(2.234(6) \AA$ ) is longer than that of compound 13 (2.194(1) $\AA$ ) (see Figures S88 and S92). In compound 14, the copper atom is dicoordinate with a sulphur and chlorine atom; it has a linear geometry apparent from the $\mathrm{S}-\mathrm{Cu}-\mathrm{Cl}$ bond angle of $178.04^{\circ}$ (see

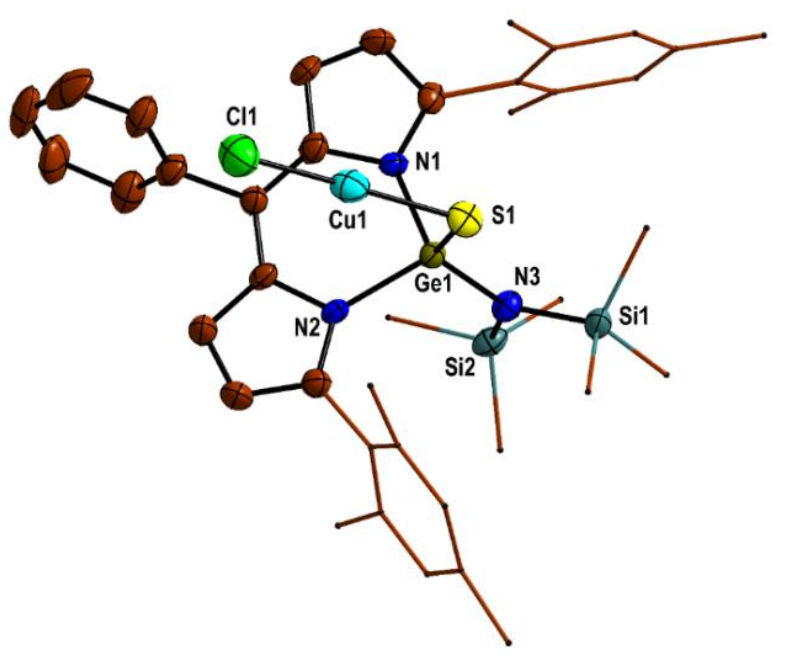

Figure 3. Molecular structure of thiogermaamide stabilized copper(I) chloride complex 14 with thermal ellipsoids at the $40 \%$ probability level. All hydrogen atoms are omitted for clarity. Selected bond lengths (Å) and angles (deg): Ge(1)-S(1) 2.132(7), Ge(1)-N(1) 1.934(1), $\mathrm{Ge}(1)-\mathrm{N}(2)$ 1.938(1), Ge(1)-N(3) 1.831(1), S(1)-Cu(1) 2.143(8), $\mathrm{Cu}(1)-\mathrm{Cl}(1)$ 2.087(2); N(3)-Ge(1)-N(1) 112.2(5), N(3)-Ge(1)-N(2) 112.0(5), N(1)-Ge(1)-N(2) 96.6(4), $\mathrm{N}(3)-\mathrm{Ge}(1)-\mathrm{S}(1)$ 116.30(4), $\mathrm{S}(1)-\mathrm{Cu}(1)-\mathrm{Cl}(1)$ 178.04(2). Data collection temperature: 100 $\mathrm{K}$.

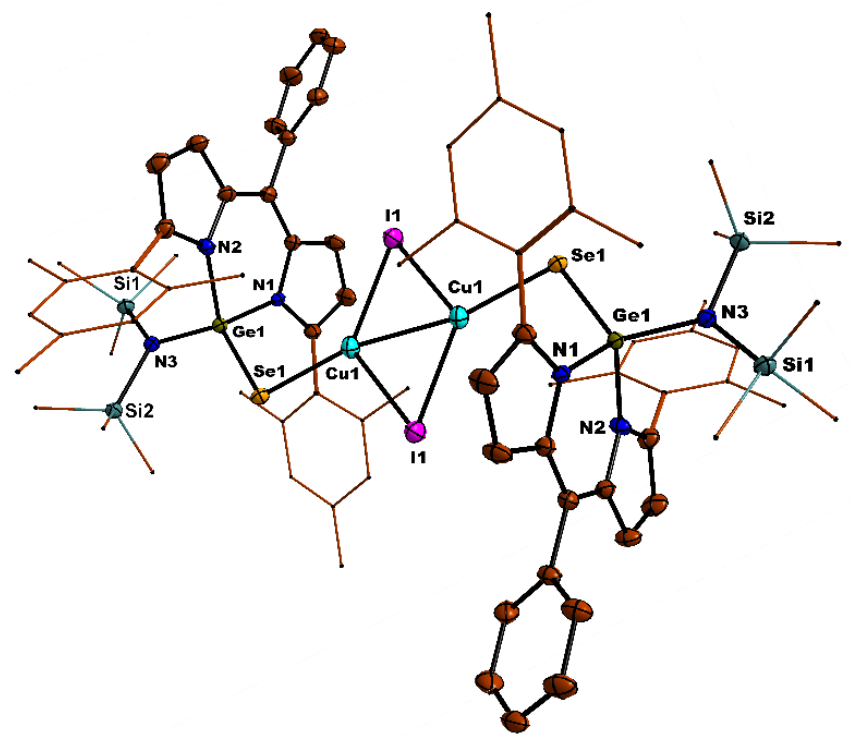

Figure 4. Molecular structure of selenogermaamide stabilized copper(I) iodide complex 19 with thermal ellipsoids at the $50 \%$ probability level. All hydrogen atoms are omitted for clarity. Selected bond lengths ( $\AA$ ) and angles (deg): Ge(1)-Se(1) 2.234(6), Ge(1)-N(1) 1.928(2), Ge(1)-N(2) 1.931(3), Ge(1)-N(3) 1.853(3), Se(1)-Cu(1) 2.349(5), $\mathrm{Cu}(1)-1(1)$ 2.566(5), $\mathrm{Cu}(1)-\mathrm{I}(1) \quad 2.632(4), \quad \mathrm{Cu} 1-\mathrm{Cu} 1 \quad 2.581(8) ; \quad \mathrm{N}(3)-\mathrm{Ge}(1)-\mathrm{N}(1) \quad 110.98(2)$ $\mathrm{N}(3)-\mathrm{Ge}(1)-\mathrm{N}(2) 105.98(2), \mathrm{N}(1)-\mathrm{Ge}(1)-\mathrm{N}(2) 94.50$ (1), Ge(1)-Se(1)-Cu(1) 102.18(2), I(1)$\mathrm{Cu}(1)-1(1)$ 120.47(2), Se(1)-Cu(1)-I(1) 133.05(2). Data collection temperature: $100 \mathrm{~K}$.
Figure S89). The $\mathrm{Cu}-\mathrm{Cl}$ bond in compound $14(2.087(2) \AA)$ is marginally shorter than that in thiosilaamide stabilized dicoordinate copper(I) chloride complex (2.095 ̊̊). ${ }^{46}$ The complexes 16, 17, and 19 have a planar dimeric $\mathrm{Cu}_{2} \mathrm{X}_{2}(\mathrm{X}=\mathrm{Br}, \mathrm{I})$ core; the copper atoms are tricoordinate with the sum of bond angles around them, equalling $360^{\circ}$. The average $\mathrm{Cu}-\mathrm{l}$ bond lengths in compounds 17 ( $2.604 \AA$ ) and 19 (2.599 $\AA$ ) is comparable to that in germylene stabilized dimeric

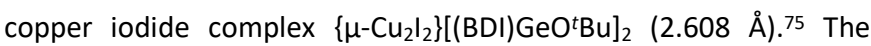
Cu...Cu distance in compounds 16 (2.725(5) $\AA), 17$ (2.699(8) $\AA$ ), and $19(2.581(8) \AA)$ is less than the sum of the Van der Waals radii of two copper atoms $(2.80 \AA)$ and indicates the presence of cuprophilic interaction (see Figures S90-92).

\section{Conclusions}

The first examples of germacarbonyl compounds 3-4, 6-7, 9-10, and 12-13 that are stable under ambient conditions were synthesized and structurally characterized. Though germanones, germacarboxylic acids, and germaesters did not bind with copper(I) halides, germaamides did react at ambient conditions providing copper(I) complexes (14-19) that are also stable outside inert atmospheres. The air and water stabilities of these germacarbonyl compounds and copper(I) complexes were studied using ${ }^{1} \mathrm{H}$ NMR spectroscopy; the stability of these compounds is due to the precise thermodynamic and kinetic stabilizations provided by bulky dipyrromethene ligand. Uniquely, selective binding of thiogermaamide $\mathbf{1 2}$ and selenogermaamide 13 towards $\mathrm{Cu}(\mathrm{I}) \mathrm{Cl}$ and $\mathrm{Cu}(\mathrm{I}) \mathrm{Br}$ was noticed when they were reacted with a mixture of $\mathrm{Cu}(\mathrm{I}) \mathrm{X}$ salts, respectively $(\mathrm{X}=\mathrm{Cl}, \mathrm{Br}, \mathrm{I})$.

\section{Author Contributions}

P. M. carried out the experimental studies and drafted the manuscript. P. S. and P. C. J. helped P. M. during (a) dipyrromethene synthesis and (b) monitoring the air and water stability of reported compounds. D. S. assisted P. M. during the crystallographic studies on compounds 14,16 , and 17 . S. N. corrected the manuscript.

\section{Acknowledgments}

P. M. and P. S. thank IIT Delhi for research fellowships. P. C. J. and D. S. thank CSIR, New Delhi, India, for research fellowships. S. N. thanks SERB, DST, New Delhi, India, for funding (EMR/2017/005519) and DST-FIST for establishing a single-crystal X-ray diffraction facility (SR/FST/CSII-027/2014) in the Department of Chemistry, IIT Delhi.

\section{Conflicts of Interest}

There are no conflicts to declare

\section{Notes and References}

1. Y. K. Loh and S. Aldridge, Angew. Chem. Int. Ed., 2021, 60, 8626-8648. 
2. Y. Xiong, S. Yao and M. Driess, Angew. Chem. Int. Ed., 2013, 52, 4302-4311.

3. M. Asay, C. Jones and M. Driess, Chem. Rev., 2011, 111, 354-396.

4. R. C. Fischer and P. P. Power, Chem. Rev., 2010, 110, 38773923.

5. Y. Mizuhata, T. Sasamori and N. Tokitoh, Chem. Rev., 2009, 109, 3479-3511.

6. S. Nagendran and H. W. Roesky, Organometallics, 2008, 27, 457-492.

7. R. Okazaki and N. Tokitoh, Acc. Chem. Res., 2000, 33, 625630.

8. P. P. Power, Chem. Rev., 1999, 99, 3463-3503.

9. M. C. Kuchta and G. Parkin, Coord. Chem. Rev., 1998, 176, 323-372.

10. Y. Xiong, S. Yao and M. Driess, J. Am. Chem. Soc., 2009, 131, 7562-7563.

11. S. Yao, Y. Xiong and M. Driess, Chem. Commun., 2009, 6466-6468.

12. P. Arya, J. Boyer, F. Carr, R. Corriu, G. Lanneau, J. Lapasset, M. Perrot, and C. Priou, Angew. Chem. Int. Ed., 1989, 28, 1016-1018.

13. N. Tokitoh, T. Matsumoto, K. Manmaru and R.Okazaki, J. Am. Chem. Soc., 1993, 115, 8855-8856.

14. T. Matsumoto, N. Tokitoh and R. Okazaki, Angew. Chem. Int. Ed., 1994, 33, 2316-2317.

15. N. Tokitoh, T. Matsumoto and R. Okazaki, J. Am. Chem. Soc., 1997, 119, 2337-2338.

16. M. Saito, N. Tokitoh and R. Okazaki, J. Am. Chem. Soc., 2004, 126, 15572-15582.

17. W.-P. Leung, W.-H. Kwok, L. T. C. Law, Z.-Y. Zhou and T. C. W. Mak, Chem. Commun., 1996, 505-506.

18. N. Parvin, N. Sen, P. V. Muhasina, S. Tothadi, P. Parameswaran and S. Khan, Chem. Commun., 2021, 57, 5008-5011.

19. I. Alvarado-Beltran, A. Rosas-Sánchez, A. Baceiredo, N. Saffon-Merceron, V. Branchadell and T. Kato, Angew. Chem. Int. Ed., 2017, 56, 10481-10485.

20. M. M. Linden, H. P. Reisenauer, D. Gerbig, M. Karni, A. Schäfer, T. Müller, Y. Apeloig and P. R. Schreiner, Angew. Chem. Int. Ed., 2015, 54, 12404-12409.

21. S. U. Ahmad, T. Szilvási, E. Irran and S. Inoue, J. Am. Chem. Soc., 2015, 137, 5828-5836.

22. T. Muraoka, K. Abe, H. Kimura, Y. Haga, K. Ueno and Y. Sunada, Dalton Trans., 2014, 43, 16610-16613.

23. A. C. Filippou, B. Baars, O. Chernov, Y. N. Lebedev and G Schnakenburg, Angew. Chem. Int. Ed., 2014, 53, 565-570.

24. S. S. Sen, Angew. Chem. Int. Ed., 2014, 53, 8820-8822.

25. R. Rodriguez, T. Troadec, D. Gau, N. Saffon-Merceron, D. Hashizume, K. Miqueu, J.-M. Sotiropoulos, A. Baceiredo and T. Kato, Angew. Chem. Int. Ed., 2013, 52, 4426-4430.

26. T. Muraoka, K. Abe, Y. Haga, T. Nakamura and K. Ueno, J. Am. Chem. Soc., 2011, 133, 15365-15367.

27. Y. Gao, H. Hu and C. Cui, Chem. A Eur. J., 2011, 17, 88038806.

28. S. Yao, Y. Xiong, W. Wang and M. Driess, Chem. A Eur. J., 2011, 17, 4890-4895.
29. S. Yao, Y. Xiong and M. Driess, Chem. A Eur. J., 2010, 16, 1281-1288.

30. Y. Xiong, S. Yao and M. Driess, Dalton Trans., 2010, 39, 9282-9287.

31. Y. Xiong, S. Yao, R. Müller, M. Kaupp and M. Driess, Nat. Chem., 2010, 2, 577-580.

32. J. D. Epping, S. Yao, M. Karni, Y. Apeloig and M. Driess, J. Am. Chem. Soc., 2010, 132, 5443-5455.

33. X. Zhao, T. Szilvási, F. Hanusch and S. Inoue, Chem. A Eur. J., 2021, 1-5.

34. D. Sarkar, C. Weetman, S. Dutta, E. Schubert, C. Jandl, D. Koley and S. Inoue, J. Am. Chem. Soc., 2020, 142, 1540315411.

35. M. K. Sharma, S. Sinhababu, P. Mahawar, G. Mukherjee, B. Pandey, G. Rajaraman and S. Nagendran, Chem. Sci., 2019, 10, 4402-4411.

36. S. Sinhababu, D. Yadav, S. Karwasara, M. K. Sharma, G. Mukherjee, G. Rajaraman and S. Nagendran, Angew. Chem. Int. Ed., 2016, 55, 7742-7746.

37. L. Li, T. Fukawa, T. Matsuo, D. Hashizume, H. Fueno, K. Tanaka and K. Tamao, Nat. Chem., 2012, 4, 361-365.

38. S. Yao, Y. Xiong, W. Wang and M. Driess, Chem. A Eur. J., 2011, 17, 4890-4895.

39. H. Suzuki, N. Tokitoh, S. Nagase, and R. Okazaki, J. Am. Chem. Soc., 1994, 116, 11578-11579.

40. H. Suzuki, N. Tokitoh, R. Okazaki, S. Nagase and M. Goto, J. Am. Chem. Soc., 1998, 120, 11096-11105.

41. N. Tokitoh, T. Sadahiro, K. Hatano, T. Sasaki, N. Takeda and R. Okazaki, Chem. Lett., 2002, 31, 34-35.

42. G. Tan, Y. Xiong, S. Inoue, S. Enthaler, B. Blom, J. D. Epping and M. Driess, Chem. Commun., 2013, 49, 5595.

43. Y. Xiong, S. Yao, S. Inoue, E. Irran and M. Driess, Angew. Chem. Int. Ed., 2012, 51, 10074-10077.

44. A. Mitra, J. P. Wojcik, D. Lecoanet, T. Müller and R. West, Angew. Chem. Int. Ed., 2009, 48, 4069-4072.

45. T. Iwamoto, K. Sato, S. Ishida, C. Kabuto and M. Kira, J. Am. Chem. Soc., 2006, 128, 16914-16920.

46. N. Parvin, S. Pal, S. Khan, S. Das, S. K. Pati and H. W. Roesky, Inorg. Chem., 2017, 56, 1706-1712.

47. N. Fujita, L. Li, N. Lentz, S. Konaka, A. Kuroda, R. Ohno, N. Hayakawa, K. Tamao, D. Madec, T. Kato, A. Rosas-Sánchez, D. Hashizume and T. Matsuo, Chem. Lett., 2020, 49, 141144.

48. R. K. Siwatch, S. Karwasara, M. K. Sharma, S. Mondal, G. Mukherjee, G. Rajaraman and S. Nagendran, Organometallics, 2016, 35, 429-438.

49. B. Prashanth and S. Singh, Dalton Trans., 2016, 45, 60796087.

50. S. Karwasara, R. K. Siwatch, C. K. Jha and S. Nagendran, Organometallics, 2015, 34, 3246-3254.

51. S. Karwasara, D. Yadav, C. K. Jha, G. Rajaraman and S. Nagendran, Chem. Commun., 2015, 51, 4310-4313.

52. B. Li, Y. Li, N. Zhao, Y. Chen, Y. Chen, G. Fu, H. Zhu and Y. Ding, Dalton Trans., 2014, 43, 12100-12108.

53. D. Yadav, R. K. Siwatch, G. Mukherjee, G. Rajaraman and S. Nagendran, Inorg. Chem., 2014, 53, 10054-10059.

54. R. K. Siwatch, D. Yadav, G. Mukherjee, G. Rajaraman and S. 
Nagendran, Inorg. Chem., 2014, 53, 5073-5079.

55. S. Karwasara, M. K. Sharma, R. Tripathi and S. Nagendran, Organometallics, 2013, 32, 3830-3836.

56. S. Sinhababu, R. K. Siwatch, G. Mukherjee, G. Rajaraman and S. Nagendran, Inorg. Chem., 2012, 51, 9240-9248.

57. R. K. Siwatch and S. Nagendran, Organometallics, 2012, 31, 3389-3394.

58. A. Jana, H. W. Roesky, C. Schulzke, P. P. Samuel and A. Döring, Inorg. Chem., 2010, 49, 5554-5559.

59. W.-P. Leung, K.-H. Chong, Y.-S. Wu, C.-W. So, H.-S. Chan and T. C. W. Mak, Eur. J. Inorg. Chem., 2006, 2006, 808812.

60. L. W. Pineda, V. Jancik, R. B. Oswald and H. W. Roesky, Organometallics, 2006, 25, 2384-2387.

61. L. W. Pineda, V. Jancik, H. W. Roesky and R. Herbst-Irmer, Angew. Chem. Int. Ed., 2004, 43, 5534-5536.

62. Y. Ding, Q. Ma, H. W. Roesky, I. Usón, M. Noltemeyer and H. Schmidt, Dalton Trans., 2003, 1094-1098.

63. I. Saur, G. Rima, H. Gornitzka, K. Miqueu and J. Barrau, Organometallics, 2003, 22, 1106-1109.

64. Y. Ding, Q. Ma, I. Usón, H. W. Roesky, M. Noltemeyer and H.-G. Schmidt, J. Am. Chem. Soc., 2002, 124, 8542-8543.

65. S. R. Foley, G. P. A. Yap and D. S. Richeson, J. Chem. Soc. Dalton Trans., 2000, 1663-1668.

66. T. Matsumoto, N. Tokitoh and R. Okazaki, J. Am. Chem. Soc., 1999, 121, 8811-8824.

67. G. Ossig, A. Meller, C. Brönneke, O. Müller, M. Schäfer and R. Herbst-Irmer, Organometallics, 1997, 16, 2116-2120.

68. S. R. Foley, C. Bensimon and D. S. Richeson, J. Am. Chem. Soc., 1997, 119, 10359-10363.

69. M. Kirchmann, T. Gädt, F. M. Schappacher, R. Pöttgen, F. Weigend and L. Wesemann, Dalton Trans., 2009, 10551062.

70. P. Mahawar, M. K. Wasson, M. K. Sharma, C. K. Jha, G. Mukherjee, P. Vivekanandan and S. Nagendran, Angew. Chem. Int. Ed., 2020, 59, 21377-21381.

71. C. K. Jha, S. Karwasara, and S. Nagendran, Chem. Eur. J., 2014, 20, 10240 - 10244.

72. S. Yadav, R. Kumar, K. V. Raj, P. Yadav, K. Vanka and S. S. Sen, Chem. An Asian J., 2020, 15, 3116-3121.

73. S. Sinhababu, M. K. Sharma, P. Mahawar, S. Kaur, V. K. Singh, A. Paliwal, D. Yadav, H. K. Kashyap and S. Nagendran, Dalton Trans., 2019, 48, 16366-16376.

74. H. C. E. McFarlane and W. McFarlane, in J. Mason(ed.): Multinuclear NMR, pp. 417-435, Plenum Press, New York (1987).

75. L. Ferro, P. B. Hitchcock, M. P. Coles and J. R. Fulton, Inorg. Chem., 2012, 51, 3, 1544-1551. 